\title{
MARKI KOLOŃSKIE CZY LIWRY FRANCUSKIE, CZYLI O FINANSOWANIU I PRZELICZNIKACH WALUTOWYCH PODCZAS IV WYPRAWY KRZYŻOWEJ, W ŚWIETLE UMOWY Z KWIETNIA 1201 ROKU ORAZ KRONIK GEOFFROY'A DE VILLEHARDOUIN I ROBERTA Z CLARI
}

\author{
ZDZISŁAW PENTEK
}

\begin{abstract}
Cologne marcs or French livres, or financing and currency conversions during the 4th Crusade, in the light of the agreement of April 1201 and the chronicles of Geoffroy de Villehardouin and Robert of Clari. The paper focuses on the financing of the 4th crusade and the agreement of April 1201 among the future leaders of the crusade with Venice. I discuss the problem of the currency conversion of Cologne marks and French livres in the chronicles of Geoffroy de Villehardouin and Robert of Clari. It has been established that the sum of 50000 livres paid by the crusaders and mentioned by Robert Clari is not real. Actually, it was the sum of 50000 Cologne marks, which had a much lower value. If the sum were 50000 French livres, it would cover the cost the crusaders committed to bear, because 50000 livres equaled at the time 20450 kilograms of silver, and the whole sum the crusaders were obliged to pay was 85000 Cologne marks or 19890 kilograms of silver. Yet, it is known that having paid the 50000 livres and adding a thousand collected by the soldiers, there remained a debt of 34000 Cologne marks, which the crusaders had to work off in Venetian service. The organizers of the 4th crusade overestimated the number of its future participants and they concluded an agreement with Venice exaggerating the future development. They ordered the construction of the fleet and provisions for one year for too many expected crusade participants. In result, those who turned up for the crusade were not able to cover its huge costs.
\end{abstract}

STRESZCZENIE. Artykuł dotyczy finansowania IV krucjaty oraz umowy przyszłych przywódców krucjaty z Wenecją zawartej w kwietniu 1201 roku. Poruszono kwestie przeliczników walutowych marki kolońskiej i liwrów francuskich, o których piszą kronikarze Robert z Clari i Geoffroy de Villehardouin. Ustalono, że podana przez Roberta z Clari kwota zapłacona przez krzyżowców Wenecji opiewająca na 50 tys. liwrów jest niezgodna z realiami. W rzeczywistości było to 50 tys. marek kolońskich, które miały znacznie mniejszą wartość. Gdyby to były liwry francuskie wystarczyłyby one na pokrycie całej kwoty, którą krzyżowcy zobowiązali się zapłacić, bowiem 50 tys. liwrów było wówczas równe $20450 \mathrm{~kg}$ srebra, a cała suma, jaką krzyżowcy zobowiązali się opiewała na 85 tys. marek kolońskich, czyli $19890 \mathrm{~kg}$ srebra. Tymczasem wiadomo, że po zapłaceniu owych 50 tys. i dodatkowego tysiąca zebranego przez żołnierzy pozostał jeszcze dług 34 tys. marek kolońskich, które krzyżowcy musieli odpracować na służbie weneckiej. Organizatorzy IV krucjaty znacznie przeszacowali liczbę przyszłych jej uczestników i zawarli umowę z Wenecją znacznie na wyrost, zamawiając budowę floty i prowiant na czas jednego roku dla zbyt dużej liczby uczestników wyprawy. W rezultacie ci, którzy stawili się na wyprawę, nie byli w stanie pokryć ogromnych jej kosztów.

Author: Zdzisław Pentek, Wydział Historyczny UAM, ul. Uniwersytetu Poznańskiego 7, 61-614 Poznań, zp26@amu.edu.pl, ORCID iD: https://orcid.org/0000-0001-6500-6559

Keywords: Fourth Crusade, Venice, Constantinople, Robert de Clari, Geoffroy de Villehardouin, Financing of the Crusades.

Słowa kluczowe: IV krucjata, Robert z Clari, Geoffroy de Villehardouin, Wenecja, Konstantynopol, finansowanie krucjat.

Balcanica Posnaniensia. Acta et studia, XXVI, Poznań 2019, Wydawnictwo Instytutu Historii UAM, pp. 83-92, ISBN 978-83-66355-32-3, ISSN 0239-4278. Polish text with summaries in English and Polish.

doi.org/10.14746/bp.2019.26.5 
Zagadnieniami finansowania krucjat na dobrą sprawę rozpoczęto interesować się w XX wieku. Wynikało to stąd, że do końca XIX wieku koncentrowano się przede wszystkim na problemach ukazania historii politycznej wypraw krzyżowych. Materiał źródłowy o krucjatach nie uległ jakiemuś wzmocnieniu jakościowemu i ilościowemu, jednak w XX wieku rozpoczęto go analizować pod zupełnie innymi kątami. Zdaje się pierwszym badaczem, który przyjrzał się pobieżnie sprawie finansowania krucjat był francuski mediewista, profesor Sorbony, Ferdinand Lot (1866-1952) ${ }^{1}$. Później, Ronald P. Grossman (ur. 1934) w 1965 roku opublikował blisko dwustustronicową pracę doktorską na Uniwersytecie w Chicago, The financing of the Crusades. ${ }^{2}$ Brytyjski historyk, Giles Constable (ur. 1929) w 1982 roku wydał krótkie studium o finansowaniu ruchu krucjatowego w XII wieku. ${ }^{3}$ Problem został dostrzeżony również w siedem lat potem w VI tomie History od the Crusades pod redakcją K. M. Settona. Dowodem tego jest osobny rozdział o finansowaniu krucjat autorstwa Freda A. Cazel, Jr (19212011). ${ }^{4}$ Swój głos w sprawie finansowania IV krucjaty, oddali również w 1997 roku, Donald Queller i Thomas Madden, w The fourth crusade. ${ }^{5}$ Dalsze badania podjęła amerykańska badaczka Bizancjum, Ece Gülsüm Turnator, która zaprezentowała swe wnioski w opasłym doktoracie obronionym na Uniwersytecie Harvarda (2013): Turning the Economic Tables in the Medieval Mediterranean. The Latin Crusader Empire and the Transformation of the Byzantine Economy, ca. 1100-1400, jednak nie porusza spraw związanych z IV krucjatą. ${ }^{6}$

Tytułem wstępu, należy odnieść się do spraw związanych z zapotrzebowaniem na środki finansowe, które pokrywały koszty udziału w krucjatach. Krucjaty z finansowego punktu widzenia były niezwykle kosztochłonne. Siłą rzeczy, udziałem w krucjatach interesowały się elity rycerskie. W praktyce, tylko ta grupa mogła unieść finansowy ciężar udziału w wyprawie do Ziemi Świętej. Zatem, by pozyskać fundusze chwytano się różnych sposobów. Warto się przyjrzeć niektórym z nich.

${ }^{1}$ F. Lot, L'art militaire et les armées au Moyen Âge en Europe et le Proche Orient, t. 1, Paris 1946; toż po polsku jako Historia wojen i wojskowości w średniowieczu, tom 1, thumaczenie Dominik Jednorowski, Oświęcim 2018.

2 R P. Grossman, The financing of the Crusades, Chicago 1965.

${ }^{3}$ G. Constable, The financing of the crusades in the Twelfth Century, w: Outremer. Studies in the history of the Kingdom Jerusalem, red. B. Z. Kedar et a., Jerusalem 1982, s. 64-88 i osobno G. Constable, Crusaders and Crusading in the Twelfth Century, Farnham 2008, s. 117-142.

${ }^{4}$ F. A. Cazel, Financing the Crusades, w: A History of the Crusades, t. 6, red. K. Seeton, Madison 1989, s. 116-149.

${ }^{5}$ D. E. Queller, Th. F. Madden, The Fourth Crusade. The Conquest of Constantinople, Philadephia 1997, s. 198-201, 217-218, 294-295.

${ }^{6}$ E. G. Turnator, Turning the Economic Tables in the Medieval Mediterranean. The Latin Crusader Empire and the Transformation of the Byzantine Economy, ca. 1100-1400, Cambridge, Mass. 2013. Tytułem uzupełnień można dodać jeszcze publikacje z ostatniego czasu, ale nie analizujących tego tematu: J. H. Pryor, Logistics and Warfare in the Age of the Crusades, Aldershot 2006; T. F. Madden (ed.) The Fourth Crusade; Event, Aftermath, and Perceptions: papers from the sixth conference of the Society for the Study of the Crusades and the Latin East, Istanbul, Turkey,25-29 August 2004, Hampshire 2008. 
Robert II Krótkoudy (1054-1134), najstarszy syn Wilhelma Zdobywcy, aby móc sfinansować wyprawę i zabrać swe hufce, zastawił księstwo Normandii, a dzięki temu otrzymał 10000 srebrnych marek od swego brata Wilhelma II Rudego, króla Anglii (1087-1100)7 . Z kolei inny uczestnik I krucjaty, książę lotaryński Gotfryd z Bouillon, sprzedał hrabstwo Verdun oraz inne ziemie biskupom z Liège i Verdun. W 1101 roku wicehrabia Bourges, Eudes (Idzi) Arpin (1060-1109), odsprzedał swoje posiadłości w Bourges i Dun-le-Poëlier królowi Filipowi I za sumę 60000 sou ${ }^{8}$. Kronikarz Wilhelm z Newburgh wspominał, że uczestnik III krucjaty, król Anglii Ryszard Lwie Serce (1189-1199), zbierając fundusze na podróż do Ziemi Świętej, odgrażał się, że sprzeda Londyn, jeżeli znajdzie kupca ${ }^{9}$. Londyn nie został wprawdzie przez nikogo kupiony, jednak król uciekł się do innych metod pozyskiwania pieniędzy. Monarcha ten, najpierw wykorzystał środki pozostawione przez ojca, Henryka II (1154-1189), następnie zwiększył obciążenie fiskalne w swoim państwie oraz nałożył tzw. „dziesięcinę Saladyna" (The Saladin tithe lub the Aid of 1188). Dalej, król anulował traktat w Falaise z 1174 roku, nakładający finansowe zobowiązania na władcę Szkocji Wilhelma I Lwa (1165-1214), który musiał pokrywać koszty okupacji angielskiej. Angielski monarcha zamienił to na jednorazową wypłatę 10000 srebrnych marek. ${ }^{10}$ Monarcha też zaczął sprzedawać dobra ziemskie i urzędy. Ta praktyka dotknęła także tych, którzy pełnili już powierzone im urzędy, czego przykładem był lord kanclerz, William Longchamp (zm. 1197), zmuszony zapłacić sumę 3000 funtów na rzecz monarchy. ${ }^{11}$ Natomiast król Francji, Filip II August (1180-1223), towarzysz Ryszarda na tej krucjacie, posunął się jeszcze dalej. Obłożył on podatkiem wszystkich tych, którzy nie wybrali się z nim do Ziemi Świętej, była to francuska wersja tzw. „dziesięciny Saladyna" (la dîme Saladine). ${ }^{12}$ W 1215 roku papież Innocenty III (1198-1216), wolą Soboru Laterańskiego zobowiązywał do specjalnego podatku na sprawy krucja-

${ }^{7}$ Chronicon Hugonis, red. H. Pertz, MGH SS 8, Hannovaere 1848, s. 472; Ch. W. Dawid, Robert Curthose. Duke of Normandy, Cambridge Mass. 1920, s. 90-92.

8 Paris, Bibl. Sainte-Geneviève, ms. 0782, f. 230; J. Riley-Smith, The first crusaders, 1095-1131, Cambridge 1997, s. 154; G. Constable, The three lives of Odo Arpinus: Viscount of Bourges, crusader, monk of Cluny, w: Crusaders and Crusading in the Twelfth Century, Ashgate 2008, s. 215-228.

${ }^{9}$ William of Newburgh, Chronicles of the Reigns of Stephen, Henry II and Richard I. Historia rerum Anglicarum, red. Richard Howlett, London 1884, t. 1, s. 306 [Rolls Series 82] oraz Roger of Howden, Chronica, red. William Stubbs, t. 3, London 1869-1871, s. 13.

${ }^{10}$ D. Carpenter, The Struggle for Mastery: Britain, 1066-1284, Oxford 2003, s. 226, 230.

${ }^{11}$ A. E. Conway, The family of William Longchamp. Bishop of Ely, chancellor and justiciar of England, 1190-1191, „Archaeologia Cantiana” 1923, t. 36, s. 15.

${ }^{12}$ Ordonnances des rois de France de la troisième race,.... Onzième volume, Contenant les ordonnances de Charles VI, données depuis le commencement de l'année 1419 jusqu'à la fin du règne de ce prince... par M. de Vilevault,... et M. de Bréquigny, Paris 1769, s. 255; Caesaris Baronii Annales ecclesiastici a Christo nato ad annum 1198, Paris-Freiburg 1880, t. 19, s. 566; P. Gagnol, Les dédimes et les dons gratuits, „Revue d'histoire, de l'Église de France” 1911, t. 2, s. 465-466. 
towe ${ }^{13}$. Oto tylko niektóre, bardziej jaskrawe przypadki radzenia sobie z niedoborami finansowymi ${ }^{14}$.

Przechodząc do meritum, pragnę się pochylić nad elementami finansowania IV krucjaty. ${ }^{15}$ Czwarta krucjata, ogłoszona przez Innocentego III, nie spotkała się zainteresowaniem chrześcijańskich monarchów, przynajmniej na tyle, aby oni sami podążyli lub choć zgłosili zamiar uczestnictwa w niej. Zresztą papież był świadomy, że jego apel może zostać przez monarchów zignorowany, tak więc do nich nie adresował swego postulatu organizacji kolejnej wyprawy do Ziemi Świętej, lecz niższego rycerstwa. Trudy zgromadzenia środków na wyprawę, spadły na ochotników, zwłaszcza tych z terenów Francji, którzy zamierzali uczestniczyć w wyprawie.

Nieodzowną pomocą służą źródła dokumentalne i narracyjne dotyczące tej wyprawy. Najważniejszym - i jego przede wszystkim należy brać pod rozwagę - jest dokument umowy krzyżowców z mającą przetransportować ich Wenecją. Pakt zawarto w kwietniu 1201 roku, ale oryginalny dokument nie zachował się. ${ }^{16}$ Wśród źródeł narracyjnych, można wyróżnić dwie tak samo zatytułowane relacje: La conquête de Constantinople, Roberta z Clari i Geoffroy'a z Villehardouin ${ }^{17}$ oraz anonimowe

13 Dokumenty soborów powszechnych. Tekst grecki, taciński, polski. Tom II (869-1312) Konstantynopol IV, Lateran I, Lateran II, Lateran III, Lataren IV, Lyon I, Lyon II, Vienne. Układ i opracowanie ks. Arkadiusz Baron, ks. Henryk Pietras, Kraków 2004, s. 314-324 (konstytucja 71).

14 F.A. Cazel, Financing the Crusades, w: A History of the Crusades, red. K. Seeton, t. 6, s. 116128.

${ }^{15}$ Kwestie finansowania IV krucjaty są rzecz jasna podnoszone bardziej lub mniej eksponowane przez historyków nie tylko tej wyprawy, zob. tylko najnowszą literaturę: D. E. Queller, Th. F. Madden, The Fourth Crusade. The Conquest of Constantinople, Philadephia 1997, s. 198-201, 217-218, 294-295, bez zwrócenia uwagi na walutę jaką podał Robert z Clari. Warto spojrzeć na koszty krucjaty przez pryzmat szacunków liczby jej uczestników sugerowane przez W. Maleczek, Petrus Capuanus. Kardinal, Legat am vierten Kreuzzug, Theologe († 1214), Wien 1988, s. 256-257. N. Sokołow, Narodziny weneckiego imperium kolonialnego, Przełożył Zdzisław Dobrzaniecki, Warszawa 1985, s. 287-288, 290, 406-407 bez żadnej refleksji nad walutami krucjaty. Nieco mniej uwagi rozważaniom o finansowaniu krucjaty podał H. E. Mayer, Geschichte der Kreuzzüge, Stuttgart-Berlin-Köln-Mainz 1985, s. 172-175 lub polskie wydanie nieco rozszerzone w porównaniu ze wzmiankowaną edycją, Historia wypraw krzyżowych, przekład Tadeusz Zatorski, Kraków 2008, s. 319; J. Phillips, Czwarta krucjata i złupienie Konstantynopola. Przekład Natalia Rataj, Mateusz Józefowicz, Kraków 2017, s. 117-118.

${ }^{16}$ Urkunden zur älteren Handels- und Staatsgeschichte der Republik Venedig mit besonderer Beziehung auf Byzanz und die Levante. I Teil: 814-1205, red. G. L. Tafel, G. M. Thomas, Wien 1856, w: Fontes rerum Austriacarum, Österreichische Geschichts-Quellen, hrsg. von der Historischen Commission der Kaiserlichen Akademie der Wissenschaften in Wien. Zweite Abteilung: Diplomataria et $a c t a$, Bd. 12, s. 362-368. Nie mamy oryginału umowy pomiędzy Wenecją i krzyżowcami, a zatem porównywać możemy tylko z jej kopiami. Jest to z pewnością skutek pożaru, gdy archiwa spłonęły w 1230 lub 1231 r.; R. Mueller, The Procurators of San Marco in the Thirteenth and Fourtheenth Centuries. A Study of the Office as a Financial and Trust Institution, „Studi Veneziani” 1971, t. 13, s. 109-110.

${ }^{17}$ Robert de Clari, La conquête de Constantinople, red. Philippe Lauer, Paris 1924 [dalej RC 1924]; Geoffroy de Villehardouin, La conquête de Constantinople, editée et traduite par Edmond Faral..., t. 1-2, Paris 1938-1939 [dalej GV 1938]. 
Devastatio Constantopolitana ${ }^{18}$. Wprawdzie autor tego ostatniego dzieła wspomina tylko o liczbie okrętów na wyprawie, ale może to być pomocne przy ustalaniu liczby uczestników wprawy.

Analizę należy rozpocząć od dokumentu podpisanego w kwietniu 1201 roku w Wenecji, pomiędzy dożą Henrykiem Dandolo a sześcioma posłami krzyżowców, którymi byli: Geoffroy z Villehardouin, Emilian z Brabancji, Konon z Béthune, Alard Maquereau, Jan z Friaise i Walter z Gaudonville ${ }^{19}$ - reprezentujących odpowiednio: Tybalda hr. Szampanii, Baldwina hr. Flandrii oraz Ludwika hr. Blois. Umowa opiewała na kwotę 85 tysięcy marek kolońskich płatną w ratach. Wenecjanie zobowiązywali się w ciągu roku wystawić flotę dla krzyżowców, mogącą przetransportować 4500 konnych, 9000 tarczowników i 20000 piechurów. Tyle wynika z dokumentu:

[XCII] [...] Petierunt itaque supradicti uiri, ut uobis nauigium daremus ad traffretandos quatuor millia quingentos millites bene armatos, et totidem equos, et nouem milia scutiferos (de quibus scutiferis, si defecerint, argentum inferius dictum nobis tamen minui non debet), et uiginti milia pedites bene armatos, cum uictualibus ad annum unum, quod eis dare promissimus. $[\ldots]^{20}$

Natomiast Villehardouin streszczający ten właśnie dokument, powoływał się na publiczne wystąpienie doży:

$[\mathbf{2 1}]<<$ Nos ferons uissiers a passer .IV. .M. et .V. .C. chevaus et .IX. mille escuiers, et es nés .IV. .M. chevaliers et .V. .C., et .XX. mille serjanz a pié; et a toz ces chevaus et ces genz iert telx la convenance que il porteront vïande a .IX. mois. Tant vos feromes al mains, en tel forme que on donra por le cheval .IV. mars et por l'ome .II.

[22] Et totes ces convenances que nos vos devisons vos tendrons par un an, des le jor que nos departirons del port de Venise a faire le servise Dieu et la crestienté, en quelque leu que ce soit. La somme de cest avoir qui ci est devant nomez, si monte .XCIV. mille mars. $>>21$

Słowem, cztery marki za każdego rumaka, a za wojownika dwie marki. Istotnie, utrzymanie 4500 koni czyni 18000 marek, zaś koszty utrzymania wojowników, w liczbie 33500 , to 67000 marek. Suma summarum, daje to 85000 srebrnych marek. Jednak z narracji Villehardouina wynika, że doża Dandolo wspominał o kwocie 94 tys. marek (nie zaś 85 tys., która wynika z dokumentu). Dlaczego Villehardouin

${ }^{18}$ Devastatio Constantinopolitana, w: C. Hopf, Chroniques greco-romaines, Berlin 1870, s. 86-92 oraz komentarze do dzieła A.J. Andrea, Historical Reflections/Réflexions Historiques, t. 19, nr 1 [Winter 1993], s. 107-129, 131-149.

${ }^{19}$ GV 1938, t. I, § 12; Z. Pentek, Cesarstwo Lacińskie 1204-1261. Kolonialne państwo krzyżowców czy Neobizancjum?, Poznań 2004, s. 36.

${ }^{20}$ Urkunden zur älteren Handels- und Staatsgeschichte der Republik Venedig mit besonderer Beziehung auf Byzanz und die Levante. I Teil: 814-1205, red. G. L. Tafel, G. M. Thomas, Wien 1856, Bd. 12, s. 365. J. Longnon, Catalogue des actes des Villehardouin, w: tenże, Recherches sur la vie de Geoffroy de Villehardouin, Paris 1939, dokument 59, s. 177-181, na podstawie rękopisów weneckich Liber Albus, fol 26r-28v i Liber pactorum, t. 1, fol. 145r-147v, opublikował treść umowy, która nie różni się od wersji z Urkunden zur älteren Handels-....

21 GV 1938, t. 1, § 21-22. 
streszczając mowę doży, podał wartość kontraktu, która była odmienna od tej, którą wcześniej zapisano? Dlaczego tak się stało?22 Jest to niejasne. Niezgodność tę próbował objaśnić jeszcze w 1939 roku Edmond Faral, wydawca krytyczny dzieła marszałka Szampanii. Zakładał on, że Villehardouin doliczył koszt utrzymania krzyżowców przez trzy miesiące w Wenecji, tj. w lipcu, sierpniu i wrześniu 1202 roku. Nie jest możliwe, aby Villehardouin wiedział w kwietniu 1201 roku, że sprawy tak się potoczą, iż liczba krzyżowców przybyłych do Wenecji w czerwcu 1202 roku będzie mniejsza od zakładanej, i będzie należało szukać nowych środków, na poczet pobytu w Wenecji w miesiącach letnich, gdyż przyjdzie jeszcze wysupłać kolejnych dziewięć tysięcy marek. Nie sądzę, aby było to możliwe do przewidzenia w 1201 roku. Nasuwają się pewne wnioski. Pierwszy z nich to taki - dla tych rozważań mniej istotny - że kronika została spisana po latach, co zresztą wiadomo od dawna, przy okazji niosąc wiadomość o ostatecznej sumie należności dla Wenecjan. Drugi wniosek może być taki, że kronikarz, zdając sobie sprawę z faktycznych zobowiązań wobec Wenecji, podał - rzekomo słowami Dandolo - realną kwotę, która była jej należna z racji umowy za pobyt oraz utrzymanie krzyżowego wojska w granicach miasta (VII-IX 1202 r.). Pogląd E. Farala w tej sprawie może być przekonywający. Odbiorca relacji Villehardouina, dowiadywał się o wielkości faktycznych zobowiązań krzyżowców wobec Wenecjan, a nie o literze umowy. Mimo wszystko są to tylko spekulacje, zwłaszcza że E. Faral poszedł w swoich rozważaniach jeszcze dalej. Próbując chyba usprawiedliwiać kronikarza, zasugerował, że umowa nie była ostateczna i z tego powodu kronikarz wspomniał o 94 tys. marek ${ }^{23}$. Taka próba wyjaśnienia zdarzeń nie ma jednak żadnego umocowania, bo nic nie wiemy o jakiejś dodatkowej klauzuli do umowy. Należy też wspomnieć, że nie ma mowy, o jakiejś usterce tekstu, bowiem te fragmenty oparte są na najstarszych rękopisach kroniki Villehardouina $O$ (II poł. XIV w.) oraz $A$ (ok. 1330) i zostały poprawnie odczytane.

Określoną w traktacie walutą, w jakiej obliczono wysokość zobowiązania były marki kolońskie. Jedna marka kolońska to około 234 gramów srebra. Daje to łączną wagę 85000 marek x 0, $234 \mathrm{~kg}=19890 \mathrm{~kg}$ srebra, czyli prawie 20 ton. Rzecz jasna, takiej ilości srebra nie posiadali wysłannicy hr. Tybalda. O ile dawać wiarę Villehardouinowi, posłowie pożyczyli w Wenecji dwa tysiące marek i przekazali je doży na poczet budowy floty ${ }^{24}$.

Drugi z dziejopisów, Robert z Clari, nieobecny przy podpisywaniu umowy, przekazał natomiast wiadomość o kwocie 87 tys. marek ${ }^{25}$. Również nie jest jasne, dlacze-

22 GV 1938, t. 1, § 21-22; Z. Pentek, Geoffroy de Villehardouin. Rycerz i kronikarz IV wyprawy krzyżowej, Poznań 1996; Geofrroy de Villehardouin, Zdobycie Konstantynopola. Z języka starofrancuskiego starofrancuskiego przetłumaczył, wstępem i komentarzami opatrzył Zdzisław Pentek, Poznań 2018, s. 12, p. 127, również nie udało mi się rozstrzygnąć, dlaczego została podana taka liczba.

${ }^{23} \mathrm{GV} 1938$ t. 1, s. 216, appendice I Ir.

${ }^{24}$ GV 1938 t. 1, § 31. Tu należy dodać, że w rękopisach $B D E$ mowa o pięciu tysiącach marek, a manuskrypcie $C$ wspomniana jest kwota sześciu tysięcy marek.

${ }^{25} \mathrm{RC} 1924 \S \mathrm{VI}$. 
go kronikarz podał kwotę niezgodną z ustaleniami zawartymi w dokumencie podpisanym w Wenecji. Można to tylko tłumaczyć niewiedzą Roberta.

Robert z Clari przykuwa uwagę czytelnika inną wiadomością. Otóż hr. Tybald, miał rzekomo pozostawić 50 tys. liwrów:

[II] [...] Et puis ne demoura mie gramment aprés que li cuens Tiebus morut, si laossa .l.m. livres as croisés... ${ }^{26}$

Jak to się ma do marki kolońskiej? Otóż liwr, to jednostka masy o wadze ok. 0,409 kg srebra, a mnożąc to przez 50 000, dowiadujemy się, że Tybald miał zgromadzić $20450 \mathrm{~kg}$ srebra. Można z tych rachunków wywieść taki wniosek, że majątek pozostawiony przez hr. Tybalda w pełni pokrywał koszty krucjaty. Ale czy tak było?

Krzyżowcy, którzy przybyli do Wenecji w roku 1202 stanęli w obliczu nieoczekiwanej sytuacji, gdyż okazało się, że jednak nie ma pieniędzy na uregulowanie długu wobec Wenecjan. Pospieszne zbiórki pieniędzy wśród krzyżowców sprawiły, że do zapłaty pozostało jeszcze 34000 marek, czyli $7956 \mathrm{~kg}$ srebra. Nie udało się zebrać pełnej kwoty, ponieważ liczba wojowników, którzy zjawili się w Wenecji była znacznie niższa niż przewidywały założenia. Rodzi się pytanie, co stało się z funduszami pozostawionymi przez hr. Tybalda? Były one przecież wystarczające, aby pokryć zobowiązanie wobec Wenecji, i to z naddatkiem. Czy relacja Roberta z Clari piszącego o 50000 liwrów jest w tej sprawie nierzetelna? Wydaje się, że właśnie tak jest. Kronikarz pomylił marki kolońskie z inną walutą, liwrami. Skutki takiej omyłki prędko się uwidaczniają, gdyż 50000 marek nie odpowiada $20450 \mathrm{~kg}$ srebra, tylko znacznie mniejszej wartości - $11700 \mathrm{~kg}$. Od kwoty 85000 marek należy wówczas odjąć 50000 marek, a nie liwrów pozostawionych przez hr. Tybalda, a wówczas do zapłaty pozostaje 35000 marek. Przeprowadzona zbiórka w sytuacji, kiedy zjawiło się w Wenecji mniej uczestników krucjaty niż przewidywano, dała tylko 1000 marek. To zaś pozwala pojąć, dlaczego do zapłaty pozostało 34000 marek. $^{27}$

Gdyby przyjąć, że przekaz Roberta jest prawdziwy, że były to liwry, a nie marki, to niezrozumiały jest brak pieniędzy na opłacenie podróży. Najprawdopodobniej więc Robert z Clari przekazał wprawdzie prawdziwą liczbę pozostawionych środków przez hr. Tybalda, tj. 50 000, ale nie były to liwry, tylko marki kolońskie, gdyż ten przelicznik obowiązywał w kontrakcie z Wenecją. Geoffroy z Villehardouin, Szampańczyk i Robert z Clari, Pikardyjczyk, poruszali się w systemie płatniczym Królestwa Francji, tj. liwrach i sou (dowodem czego jest to, że Robert wspomina o cenie kurczaka właśnie w sou ${ }^{28}$. Marszałek Villehardouin, powiada, że hr. Tybald rozdzielił pieniądze pomiędzy swoich ludzi, którzy mieli przeznaczyć na je krucjatę

26 Ibidem, § II.

27 GV 1938 t. $1, \S 61$ i 63.

${ }^{28}$ Ibidem, § LX, zob. Z. Pentek, The Fourth Crusade and the Problem of Food Provision in the Accounts of Robert de Clari and Geoffroy de Villehardouin, „Studia Historiae Oeconomicae” 2014, t. 32, s. 109-114. 
z Wenecji. Czy było to właśnie owe 50 tys. marek lub równowartość w liwrach, tego kronikarz już nie napisał. ${ }^{29}$

Jak to się ma do wydatków na inne krucjaty? Na ten temat wiemy bardzo niewiele. Suma żądana przez Wenecjan nie wydaje się wzięta znikąd. Nieco wcześniej, w 1190 roku król Filip August udający się z pomocą floty Genui do Ziemi Świętej, zamówił okręty dla 650 rycerzy, 1300 koni, tyluż giermków, płacąc 9 marek za rycerza, dwa konie i dwóch giermków, za osiem miesięcy, co daje 13, 5 marki za rok $^{30}$, czyli ogółem roczny koszt wyprawy wynosił 8775 marek. Wyprawa pod auspicjami króla Francji była mniej liczna niż nadzieje organizatorów IV krucjaty. Wniosek jest oczywisty, organizatorzy IV krucjaty znacznie przeszacowali liczbę przyszłych jej uczestników i zawarli umowę z Wenecją znacznie na wyrost, zamawiając budowę floty i prowiant na czas jednego roku dla zbyt dużej liczby uczestników wyprawy. W rezultacie ci, którzy stawili się na wyprawę, nie byli w stanie pokryć ogromnych jej kosztów.

Wenecjanie zobowiązali się prolongować dług krzyżowców i uczynili z nich zbrojne ramię przeciwko Zadarowi. W 1203 roku znalazł się jeszcze jeden potencjalny darczyńca na rzecz wzmocnienia finansów krucjaty. Był nim zbiegły z niewoli książę Aleksy Angelos, późniejszy cesarz bizantyński, Aleksy V. Obiecywał on wesprzeć krucjatę pieniędzmi, których nie posiadał i zasilić wojska krzyżowców w Palestynie liczbą pięciuset wojowników. ${ }^{31}$ Obie zapowiedzi prędko okazały się nierealne. Krucjata funkcjonowała dzięki rabunkom okolic Konstantynopola, tak jak wcześniej podczas żeglugi do niego, kiedy krzyżowcy ogałacali wybrzeża i wyspy greckie. ${ }^{32}$ Tak więc wojna, żywiła siebie samą.

Model finansowania IV krucjaty nie odbiegał od wcześniej wypróbowanych metod. Część środków, zresztą niewielka i nieznana nam, pochodziła z dobrowolnych zbiórek w Europie organizowanych przez Kościół i jego emisariuszy, jak Fulko z Neuilly. ${ }^{33}$ Natomiast największa liczba funduszy pochodziła z prywatnych zasobów feudałów, którzy nie mogąc sprostać zawartej umowie z Wenecją, stali się zakładnikami własnej nieroztropności. Ta sytuacja zmusiła ich do rezygnacji z prostej drogi do celu i zarabiania środków na spłacenie długu. Ostatecznie IV krucjata na tle wcześniejszych i późniejszych tego rodzaju wypraw okazała się najbardziej pod względem finansowym dochodowa. W porównaniu do wcześniejszych krucjat, zwłaszcza I, z ponad 12-tysięcznej armii zginęło bądź przepadło bez wieści relatywnie niewielu krzyżowców, natomiast zyski - te doraźne, liczone w pieniądzu, skarbach, relikwiach,

\footnotetext{
${ }^{29} \mathrm{GV} 1938$, t. $1, \S 36$.

${ }^{30}$ J. Branbury, Filip August, król Francji 1180-1223, thum. Idalia Smoczyk-Jackowiak, Oświęcim 2018, s. 90.

${ }^{31}$ GV 1938 t. $1, \S 92-93$.

32 Ibidem, t. 1, § 143; H. E. Mayer, Historia wypraw krzyżowych, przekład Tadeusz Zatorski, Kraków 2008, s. 328-329 oszacował, że wielkość łupów zdobytych w Konstantynopolu 900000 marek, z czego 500 tys. trafiło w ręce weneckie.

${ }^{33} \mathrm{GV} 1938$ t. $1, \S 1$.
} 
jak i prestiżowe (założenie cesarstwa) - były nieporównywalnie większe. Tak to widzieli przynajmniej owi krzyżowcy, którzy jednak nigdy nie dotarli do właściwego celu, nie walczyli z muzułmanami, lecz z chrześcijanami.

\section{BIBLIOGRAFIA}

\section{Źródla:}

Chronicon Hugonis, red. H. Pertz, MGH SS 8, Hannovaere 1848.

Devastatio Constantinopolitana, w: C. Hopf, Chroniques greco-romaines, Berlin 1870.

Dokumenty soborów powszechnych. Tekst grecki, taciński, polski. Tom II (869-1312) Konstantynopol IV, Lateran I, Lateran II, Lateran III, Lataren IV, Lyon I, Lyon II, Vienne. Układ i opracowanie ks. Arkadiusz Baron, ks. Henryk Pietras, Kraków 2004.

Fontes rerum Austriacarum, Österreichische Geschichts-Quellen, hrsg. von der Historischen Commission der Kaiserlichen Akademie der Wissenschaften in Wien. Zweite Abteilung: Diplomataria et acta, Bd. 12, Wien 1856.

Geoffroy de Villehardouin, La conquête de Constantinople, editée et traduite par Edmond Faral..., t. 1, Paris 1938.

Geoffroy de Villehardouin, Zdobycie Konstantynopola. Z języka starofrancuskiego starofrancuskiego przetłumaczył, wstępem i komentarzami opatrzył Zdzisław Pentek, Poznań 2018.

Ordonnances des rois de France de la troisième race,.... Onzième volume, Contenant les ordonnances de Charles VI, données depuis le commencement de l'année 1419 jusqu'à la fin du règne de ce prince... par M. de Vilevault,... et M. de Bréquigny, Paris 1769.

Robert de Clari, La conquête de Constantinople, red. Philippe Lauer, Paris 1924, § VI.

Roger of Howden, Chronica, red. W. Stubbs, t. 3, London 1869-1871.

Urkunden zur älteren Handels- und Staatsgeschichte der Republik Venedig mit besonderer Beziehung auf Byzanz und die Levante. I Teil: 814-1205, red. G. L. Tafel, G. M. Thomas, Wien 1856, w: Fontes rerum Austriacarum, Österreichische Geschichts-Quellen, hrsg. von der Historischen Commission der Kaiserlichen Akademie der Wissenschaften in Wien. Zweite Abteilung: Diplomataria et acta, Bd. 12.

William of Newburgh, Chronicles of the Reigns of Stephen, Henry II and Richard I. Historia rerum Anglicarum, red. Richard Howlett, London 1884, t. 1, s. 306 [Rolls Series 82].

\section{Literatura:}

A History of the Crusades, red. K. Seeton, Madison 1989, t. 6.

Baronius C., Annales ecclesiastici a Christo nato ad annum 1198, Paris-Freiburg 1880, t. 19.

Branbury J., Filip August, król Francji 1180-1223, thum. Idalia Smoczyk-Jackowiak, Oświęcim 2018.

Carpenter D., The Struggle for Mastery: Britain, 1066-1284, Oxford 2003.

Cazel F. A., Financing the Crusades, w: A History of the Crusades, red. K. Seeton, Madison 1989, t. 6.

Constable G., Crusaders and Crusading in the Twelfth Century, Farnham 2008.

Constable G., The financing of the crusades in the Twelfth Century, w: Outremer. Studies in the history of the Kingdom Jerusalem, red. B. Z. Kedar et a., Jerusalem 1982.

Constable G., The three lives of Odo Arpinus: Viscount of Bourges, crusader, monk of Cluny, w: Crusaders and Crusading in the Twelfth Century, Ashgate 2008.

Conway A. E., The family of William Longchamp. Bishop of Ely, chancellor and justiciar of England, 1190-1191, „Archaeologia Cantiana” 1923, t. 36.

Dawid Ch. W., Robert Curthose. Duke od Normandy, Cambridge Mass. 1920.

Gagnol P., Les dédimes et les dons gratuits, ,Revue d'histoire, de l'Église de France” 1911, t. 2.

Grossman R P., The financing of the Crusades, Chicago 1965. 
Hopf C., Chroniques greco-romaines, Berlin 1870.

Lot F., Historia wojen i wojskowości w średniowieczu, tłum. Dominik Jednorowski, Oświęcim 2018 , t. 1.

Lot F., L'art militaire et les armées au Moyen Âge en Europe et, w: le Proche Orient, Paris 1946, t. 1.

Madden T. F. (ed.), The Fourth Crusade; Event, Aftermath, and Perceptions: papers from the sixth conference of the Society for the Study of the Crusades and the Latin East, Istanbul, Turkey, 25-29 August 2004, Hampshire 2008.

Mayer H. E., Geschichte der Kreuzzüge, Stuttgart-Berlin-Köln-Mainz 1985.

Mayer H. E., Historia wypraw krzyżowych, tłum. Tadeusz Zatorski, Kraków 2008.

Mueller R., The Procurators of San Marco in the Thirteenth and Fourtheenth Centuries. A Study of the Office as a Financial and Trust Institution, „Studi Veneziani” 1971, t. 13.

Pentek Z., Cesarstwo Łacińskie 1204-1261. Kolonialne państwo krzyżowców czy Neobizancjum?, Poznań 2004.

Pentek Z., Geoffroy de Villehardouin. Rycerz i kronikarz IV wyprawy krzyżowej, Poznań 1996.

Pentek Z., The Fourth Crusade and the Problem of Food Provision in the Accounts of Robert de Clari and Geoffroy de Villehardouin, „Studia Historiae Oeconomicae” 2014, t. 32, s. 109-114.

Phillips J., Czwarta krucjata i złupienie Konstantynopola, tłum. Natalia Rataj, Mateusz Józefowicz, Kraków 2017.

Pryor J. H., Logistics and Warfare in the Age of the Crusades, Aldershot 2006.

Queller D. E., Madden Th. F., The Fourth Crusade. The Conquest of Constantinople, Philadephia 1997.

Riley-Smith J., The first crusaders, 1095-1131, Cambridge 1997.

Sokołow N., Narodziny weneckiego imperium kolonialnego, tłum. Zdzisław Dobrzaniecki, Warszawa 1985.

Turnator E. G., Turning the Economic Tables in the Medieval Mediterranean. The Latin Crusader Empire and the Transformation of the Byzantine Economy, ca. 1100-1400, Cambridge, Mass. 2013. 